\title{
DENSITY AND DIVERSITY OF NOCTURNAL BIRDS IN OIL PALM SMALLHOLDINGS IN PENINSULAR MALAYSIA
}

\author{
MUHAMMAD SYAFIQ YAHYA*; CHONG LEONG PUAN**; SHARIFAH NUR ATIKAH* and \\ BADRUL AZHAR*
}

\begin{abstract}
Over the past half century, oil palm cultivation has been expanding rapidly throughout many developing countries. Due to its economic importance, large tracts of natural land have been converted into oil palm cultivations and where increasing sightings of nocturnal birds have been made. A survey of nocturnal birds was conducted to assess their density and diversity in the oil palm smallholdings in the Selangor state, Peninsular Malaysia. A total of 90 sampling points were established within three oil palm smallholdings. A total of 1408 individuals of 11 nocturnal bird species were recorded. Based on distance sampling techniques, the density of Spotted Wood-owl (Strix seloputo) was estimated at 7 individuals $100 \mathrm{ha}^{-1}$, followed by 15 individuals for Sunda Scops-owl (Otus lempiji), five for Barn Owl (Tyto javanica) and 79 for Large-tailed Nightjar (Caprimulgus macrurus) per every 100 ha. The presence of a high density of some nocturnal birds in oil palm smallholdings may be associated with the availability of food source and roosting structure that are linked to habitat heterogeneity in the oil palm smallholdings. Our study highlighted the potential of nocturnal bird species, other than the Barn Owl, as biological control agents in the agricultural areas.
\end{abstract}

Keywords: nocturnal birds, oil palm smallholdings, density, abundance, biological control.

Date received: 9 January 2019; Sent for revision: 12 March 2019; Accepted: 15 November 2019.

\section{INTRODUCTION}

Nocturnal birds have been said to play ecological roles in an ecosystem similar to what their diurnal counterparts do during daytime. In Peninsular Malaysia, there is a total of 21 resident nocturnal bird species comprising of two taxonomic orders, namely Strigiformes and Caprimulgiformes. They occupy various habitat types ranging from highland forests (i.e. Mountain Scops-owl, Otus spilocephalus), secondary forests (Sunda Scops-owl, Otus lempiji), wetlands (Buffy Fish-owl, Ketupa ketupu) to urban parks (Barn Owl, Tyto javanica; Large-tailed Nightjar,

* Faculty of Forestry, Universiti Putra Malaysia, 43400 UPM Serdang, Selangor, Malaysia.

** Institute of Tropical Forestry and Forest Products (INTROP), Universiti Putra Malaysia,

43400 UPM Serdang, Selangor, Malaysia.

E-mail: chongleong@upm.edu.my
Caprimulgus macrurus) (Wells, 1999; Puan et al., 2015). All nocturnal birds recorded in Peninsular Malaysia are listed as Least Concern by International Union for Conservation of Nature (IUCN), except for Reddish Scops-owl (Otus rufescens), Large Frogmouth (Batrachostomus auritus), and Gould's Frogmouth (Batrachostomus stellatus) which are listed as Near Threatened whereas the White-fronted Scops-owl (Otus sagittatus) is vulnerable (IUCN, 2018). Either in natural or man-made habitats, each nocturnal bird plays an important ecological role in an ecosystem.

In the case of man-made habitat, previous studies revealed the potential of Barn Owl as a pest control agent (Hafidzi and Naim, 2003; Puan et al., 2012; Puan, 2013). As a result, some large agriculturalbased companies have begun introducing Barn Owl by providing nest boxes for these birds in order to suppress pest population in their agricultural lands (Hafidzi and Naim, 2003; Ojwang and Oguge, 2003). For instance, Felda Global Ventures (FGV) introduced a total of 16 individuals of Barn Owl in an 
oil palm plantation in Lahad Datu, Sabah, Malaysia in order to suppress rat population and to reduce the application of rodenticide. The programme was successful as the owl's population had multiplied by $638 \%$ after 20 months (Abidin et al., 2016) which may be able to suppress the rodent population in the plantation. This can be possible because a fully grown Barn Owl can consume up to three rats per night (Hafidzi and Naim, 2003).

Over the past three decades, despite the fact that most previous studies focused on Barn Owl (i.e. Hafidzi and Naim, 2003; Naim et al., 2010; Puan et al., 2011; Abidin et al., 2016; Salim et al., 2016), there is also an increase in studies on other nocturnal birds in Malaysia over the last five years (Atikah et al., 2013; 2019; Puan et al., 2015; NajmiHanis et al., 2016; Yee et al., 2016; 2018; Yahya et al., 2016; Chang et al., 2017; Pilla et al., 2018). By using point count method, Atikah et al. (2013) made a preliminary estimation of nocturnal bird density in oil palm smallholdings located at Tanjung Karang,
Selangor, Malaysia and recorded some nocturnal bird species that were associated with forest habitats (i.e. Oriental Bay-owl, Phodilus badius; Brown Woodowl, Strix leptogrammica; Dusky Eagle-owl, Bubo coromandus and Brown Boobook, Ninox scutulata) in the man-made landscape. The aim of this study was to estimate the density of nocturnal bird species in oil palm agriculture based on distance sampling.

\section{METHOD}

\section{Study Areas}

Bird sampling took place in oil palm smallholdings (approximately 5300 ha) located at Banting $\left(2^{\circ} 47^{\prime} 48^{\prime \prime} \mathrm{N}, 101^{\circ} 31^{\prime} 10^{\prime \prime} \mathrm{E}\right)$, Tanjung Karang $\left(3^{\circ} 24^{\prime} 24^{\prime \prime} \mathrm{N}, 1^{\circ} 1^{\circ} 15^{\prime} 26^{\prime \prime} \mathrm{E}\right)$ and Sabak Bernam $\left(3^{\circ} 50^{\prime} 50^{\prime \prime} \mathrm{N}, 100^{\circ} 53^{\prime} 19^{\prime \prime} \mathrm{E}\right)$, Selangor, Peninsular Malaysia (Figure 1). The smallholdings involved in this study were privately owned and managed

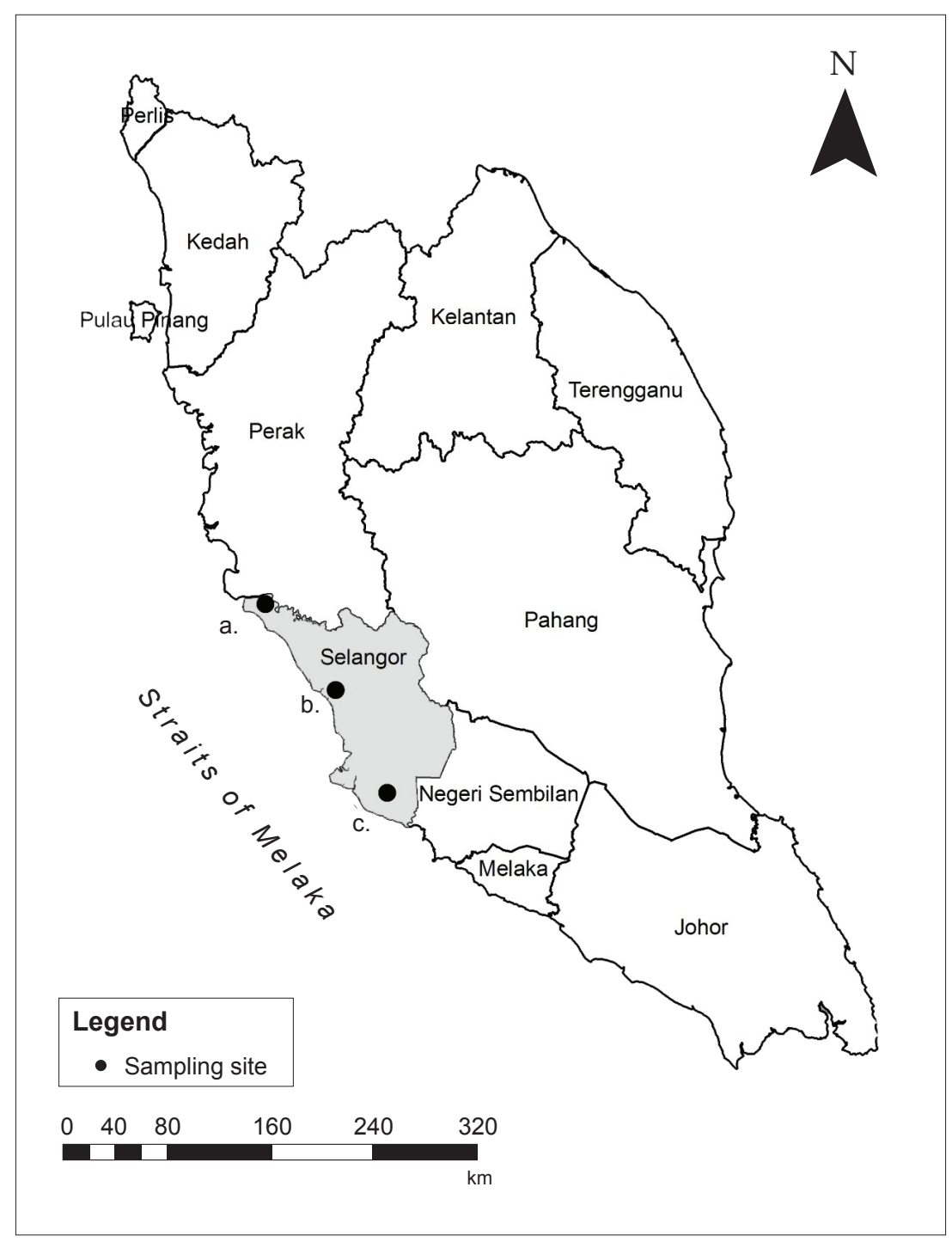

Figure 1. Locations of study areas; (a) Sabak Bernam (b) Tanjung Karang and (c) Banting in Malaysia. 
by individual land owners. Each land owners owned an average of 2-5 ha pieces of land which were primarily planted with oil palms, which sometimes intercropped with other subsistence crops (e.g. banana, coconut and jackfruit). Oil palm fruit bunches are usually harvested twice a month, throughout the year. The study areas received an average rainfall of $2500 \mathrm{~mm}$ annually (MET, 2014). There were some residential areas located within the study areas.

\section{Survey of Nocturnal Birds}

Point count survey method (adapted from Ralphs and Sauer, 1995; Buskirk and McDonald, 1995) was used in this study where 30 points were placed in each of the three study sites. Survey points were established systematically on road junctions (either tarmac or dirt roads) at $800 \mathrm{~m}$ apart, similar to previous studies at the same sites (Ghazali et al., 2016; Syafiq et al., 2016; Yahya et al., 2016; 2017). With the aid of playbacks (www.xeno-canto.org), a minimum of two experienced surveyors stayed at each point for $10 \mathrm{~min}$ and recorded all sightings and/ or vocalisations of nocturnal birds (Gerhardt, 1991; Takats et al., 2001; Delport et al., 2002; Newton et al., 2002; Kemp et al., 2009). A confirmed record was only made when both surveyors agreed upon its presence. The direct distance of each record from the sampling points was also estimated. The survey was repeated six times for each of the sampling points in order to increase the encounters of targeted birds and survey effectiveness (Hausleitner and Bio, 2006). The surveys were conducted from $1900 \mathrm{hr}-0200 \mathrm{hr}$ daily.

\section{Statistical Analyses}

Shannon-Wiener $\mathrm{H}^{\prime}$, Shannon-Weiner $\mathrm{J}^{\prime}$ and Simpson 1-D indices were used to measure the diversity of nocturnal bird species in oil palm smallholdings. We applied bootstrap estimation on the diversity index by 100 permutations to increase the precision of the calculations. Both non-permutated and permutated estimation values of the indices were reported.

By using Conventional Distance Sampling (CDS) in distance 6.2 (University of St. Andrews, United Kingdom), the density of nocturnal birds in oil palm smallholdings were estimated. Half-normal as key functions and cosine as series expansion were selected consistently throughout each estimation. In order to increase the precision of the estimations, bootstrap at 100 permutations was applied. Both estimations of density and abundance of each selected species were carried out, along with standard error (SE), coefficient of variation (\%CV), effective detection radius (EDR) and coefficient of variation) for effective detection radius (EDR\%CV). Due to insufficient data, seven species (i.e. Savanna Nightjar, Oriental Bayowl, Buffy Fish-owl, Brown Wood-owl, Dusky Eagleowl, Barred Eagle-owl Bubo sumatranus) records had to be excluded from the analysis.

\section{RESULTS}

\section{Nocturnal Bird Diversity}

A total of 1408 individuals from 11 species (comprising nine owl and two nightjar species) were recorded in this study (Table 1 and Figure 2).

TABLE 1. NOCTURNAL BIRD SPECIES RECORDED IN OIL PALM SMALLHOLDINGS AT BANTING, TANJUNG KARANG AND SABAK BERNAM, SELANGOR, PENINSULAR MALAYSIA

\begin{tabular}{llcc}
\hline Family & Species & $\begin{array}{c}\text { Number of } \\
\text { encounters }\end{array}$ & $\begin{array}{c}\text { Mean observation } \\
\text { per point }\end{array}$ \\
\hline Caprimulgidae & Large-tailed Nightjar (Caprimulgus macrurus) & 454 & 5.044 \\
& Savanna Nightjar (Caprimulgus affinis) & 20 & 0.222 \\
Tytonidae & Barn Owl (Tyto javanica) & 101 & 1.122 \\
& Oriental Bay-owl (Phodilus badius) & 15 & 0.167 \\
Strigidae & Spotted Wood-owl (Strix seloputo) & 435 & 3.83 \\
& Sunda Scops-owl (Otus lempiji) & 347 & 0.211 \\
& Buffy Fish-owl (Ketupa ketupu) & 19 & 0.144 \\
& Brown Wood-owl (Strix leptogrammica) & 13 & 0.022 \\
& Brown Hawk-owl (Ninox scutulata) & 2 & 0.011 \\
& Dusky Eagle-owl (Bubo coromandus) & 1 & 0.011 \\
\hline
\end{tabular}


Large-tailed Nightjar (454 encounters) was the most abundant species recorded followed by Spotted Wood-owl (435 encounters), Sunda Scops-owl (347 encounters) and Barn Owl (101 encounters). All the species had also been previously recorded in the oil palm smallholdings located in the Selangor state (Atikah et al., 2013; Azhar et al., 2011; 2015). Five nocturnal species that were associated with forest habitats were recorded, namely Oriental Bay-owl, Barred Eagle-owl, Dusky Eagle-owl, Brown Woodowl, and Brown Boobook (König et al., 1999; Wells,
1999; Robson, 2011), albeit their numbers remained low.

Based on Shannon-Weiner $\mathrm{H}^{\prime}$, the diversity index of nocturnal birds in oil palm smallholdings was calculated at 3.359 , or $4.731 \pm 0.004$ SE based on bootstrap estimation. For Shannon-Weiner J', the evenness index was calculated at 0.988 , or 0.9882 \pm 0.0008 SE based on bootstrap estimation. Based on Simpson 1-D, the diversity index was calculated at 0.965 or $0.9910 \pm 0.0001$ SE based on bootstrap estimation.
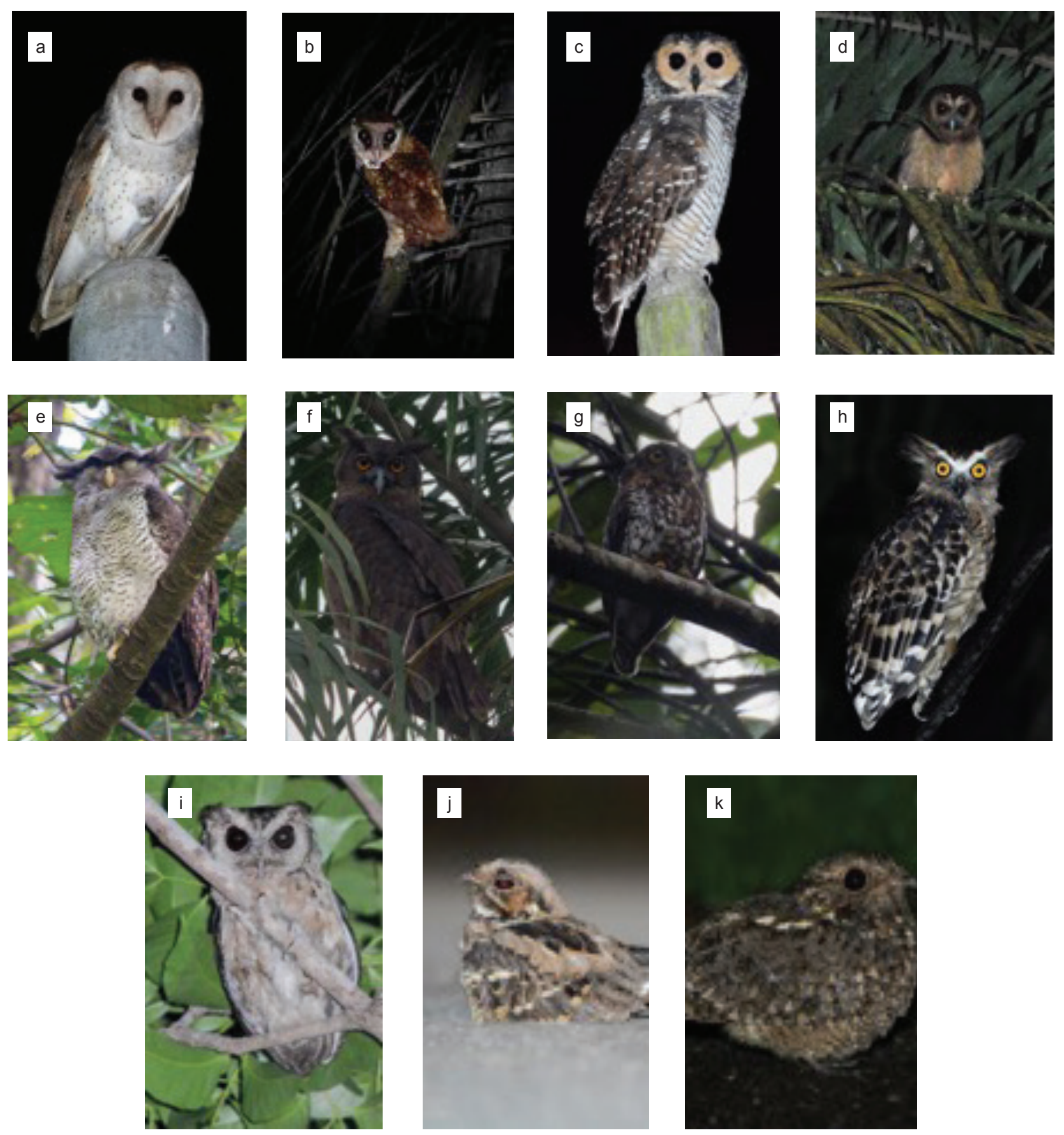

Figure 2. Nocturnal birds recorded in study areas; a) Barn owl, b) Oriental Bay-owl, c) Spotted Wood-owl, d) Brown Wood-owl, e) Barred Eagle-owl, f) Dusky Eagle-owl, g) Brown Hawk-owl, h) Buffy Fish-owl, i) Sunda Scops-owl, j) Large-tailed Nightjar, and k) Savanna Nightjar. 


\section{Nocturnal Bird Density}

By using Distance 6.0 (Thomas et al., 2010), the density of Spotted Wood-owl was estimated at 0.076 \pm 0.001 SE individual per hectare $(\% \mathrm{CV}=15.84$, $\mathrm{EDR}=94.291, \mathrm{EDR} \% \mathrm{CV}=5.04)$ or about seven individuals per 100 ha. The density of Sunda Scopsowl was estimated at $0.15 \pm 0.026 \mathrm{SE}$ individual per hectare $(\% \mathrm{CV}=16.97 \mathrm{EDR}=62.543, \mathrm{EDR} \% \mathrm{CV}$ =6.88), i.e about 15 individuals for every 100 ha. The density of Barn Owl was estimated at $0.05 \pm$ $0.011 \mathrm{SE}$ individual per hectare $(\% \mathrm{CV}=22.29 \mathrm{EDR}$ $=56.52, \mathrm{EDR} \% \mathrm{CV}=6.02$ ), about five individuals per 100 ha. For Large-tailed Nightjar, its density was estimated at $0.794 \pm 0.108 \mathrm{SE}$ individual per hectare $(\% \mathrm{CV}=13.65 \mathrm{EDR}=31.13, \mathrm{EDR} \% \mathrm{CV}=$ 1.76), about seven to eight birds in every 10 ha (Table 2). For the total area of 5200 ha, we estimated the abundance of Spotted Wood-owl at $395 \pm 62.574$ SE individuals $(\% \mathrm{CV}=15.84)$ followed by Sunda Scops-owl at $797 \pm 135.27$ SE individuals $(\% \mathrm{CV}$ $=16.97)$, Barn Owl at $263 \pm 58.624$ SE individuals $(\% \mathrm{CV}=22.29)$ and Large-tailed Nightjar at $4131 \pm$ 563.73 SE individuals $(\% \mathrm{CV}=13.65)$ (Table 3$)$.

\section{DISCUSSION}

Distance analysis estimated the density of four common nocturnal bird species, i.e. in every 100 ha of oil palm smallholdings, there were about five individuals of Barn Owl, seven Spotted Woodowls, 15 Sunda Scops-owls, and 79 Large-tailed Nightjars. The density of Large-tailed Nightjar was the highest in the smallholdings which may be due to the availability of insects as food supply and roosting sites for the bird that can be linked to habitat structure (Yahya et al., 2016).

In the case of Sunda Scops-owl, the density estimate (i.e. 1-2 individuals per $10 \mathrm{ha}$ ) is close to the estimations of Pilla et al. (2018) and Najmi-Hanis et al. (2016) in a lowland dipterocarp forest based on distance sampling and radio-telemetry methods, respectively. This is expected as the species has been known to thrive in various wooded habitats including plantations (Wells, 1999; Puan et al., 2015; Yahya et al., 2016). It should be noted that the survey covered breeding season of the species and involved call playbacks similar to Pilla et al. (2018). For the other two larger owl species, it is a little surprising that the density of Spotted Wood-owl was higher than the Barn Owl. This is unexpected as the latter is known to be abundant in oil palm plantation due to the availability of nest boxes. This calls for further investigation on whether such situation only happens in smallholdings, not in large scale oil palm plantations, as well as what factors contribute to higher density of the former in the smallholdings. Such information is essential with respect to the ecology of the species (e.g. interspecific interaction) as well as its potential to serve as a biological control agent in agricultural sector.

In addition, the presence of some forest associated species (i.e. Oriental Bay-owl, Dusky Eagle-owl and Brown Hawk-owl), although in low numbers, may also imply that smallholdings may serve as an alternative habitat for these species, at least as their hunting ground. However, it has been shown that some forest associated species may not be able to persist in oil palm agriculture (Atikah et al., 2019).

TABLE 2. DENSITIES OF NOCTURNAL BIRDS IN OIL PALM SMALLHOLDINGS IN BANTING, TANJUNG KARANG AND SABAK BERNAM, SELANGOR, PENINSULAR MALAYSIA

\begin{tabular}{lccccc}
\hline Species & D & SE & \% CV (\%) & EDR & EDR \% CV (\%) \\
\hline Spotted Wood-owl & $0.76 \times 10^{-1}$ & $0.12 \times 10^{-1}$ & 15.84 & 94.29 & 5.04 \\
Sunda Scops-owl & $1.53 \times 10^{-1}$ & $0.26 \times 10^{-1}$ & 16.97 & 62.543 & 6.88 \\
Barn Owl & $0.50 \times 10^{-1}$ & $0.11 \times 10^{-1}$ & 22.29 & 56.52 & 6.02 \\
Large-tailed Nightjar & $7.94 \times 10^{-1}$ & $1.08 \times 10^{-1}$ & 13.65 & 31.13 & 1.76 \\
Note: - density; SE - standard error; \% CV - coefficient of variations; EDR-effective distance radius; EDR\% CV - coefficient \\
of variations of effective distance variation.
\end{tabular}

TABLE 3. ABUNDANCE OF NOCTURNAL BIRDS IN OIL PALM SMALLHOLDINGS IN BANTING, TANJUNG KARANG AND SABAK BERNAM, SELANGOR, PENINSULAR MALAYSIA

\begin{tabular}{lcccrr}
\hline Species & A & SE & \% CV & \multicolumn{2}{c}{ 95\% CI } \\
\hline Spotted Wood-owl & 395 & 62.574 & 15.84 & 290 & 538 \\
Sunda Scops-owl & 797 & 135.27 & 16.97 & 573 & 110 \\
Barn Owl & 263 & 58.624 & 22.29 & 171 & 406 \\
Large-tailed Nightjar & 4131 & 563.73 & 13.65 & 3164 & 5394 \\
\hline
\end{tabular}

Note: A - abundance; SE - standard error; \%CV - percentage for coefficient of variation; $95 \%$ CI - 95\% confident interval. 


\section{CONCLUSION}

The study indicated that oil palm smallholdings are able to support high densities of some native nocturnal birds. Yet, species that are associated with forests remained low in number. It is believed that, oil palm smallholdings with higher level of habitat complexity may be able to provide a wide range of food sources as well as roosting and/or breeding sites for the nocturnal birds (Yahya et al., 2016). It is also believed that the existence of nocturnal birds in such landscape may be potentially useful to oil palm smallholders with respect to biological control of vertebrate and invertebrate pest species (Yahya et al., 2016).

\section{ACKNOWLEDGEMENT}

We wish to thank everyone who were involved and assisted in this study especially Amal Ghazali Nasron, Muhamad Syafiq Che Shaffine, Siti Asmah Muslim, Syafiq Abd Razak, Nor Laili Ibrahim, Sasidhran Selvadurai, Nur Fatin Adila Md Rashid, Raja Nazrin Raja Ahmad, Diau Ya Bing and Muhammad Ekhzarizal Mohamed Eusop. We also would like to thank the land owners for allowing us to conduct this study in their smallholdings. This study was funded by the Ministry of Education Malaysia under the Fundamental Research Grant Scheme (Project No.: 07-01-13-1184FR) and Universiti Putra Malaysia under the Research University Grant Scheme (Project No.: 03-01-11-1151RU).

\section{REFERENCES}

Abidin, C M R Z; Hafidzi, M N; Hamid, N H and Hasber, $S$ (2016). Propagation of barn owls in an oil palm plantation of Sabah: FGV's Experience. Proc. of the $9^{\text {th }}$ International Conference on Plant Protection in the Tropics ( $\left.9^{\text {th }} I C P P T\right)$. Kuching, Sarawak, Malaysia. 237 pp.

Atikah, S N; Puan, C L and Azhar, B (2013). Preliminary estimation of nocturnal bird density in oil palm agroecosystem. Proc. of the International Forestry Graduate Students Conference. (Lai, F S; Halis, R; Bakar, S N A; Ramachandran, S and Puan, C L eds.). Faculty of Forestry, Universiti Putra Malaysia, Serdang, Selangor, Malaysia. p. 50-53.

Atikah, S N; Yahya, M S; Puan, C L; Zakaria, M and Azhar, B (2019). Can forest associated nocturnal birds persist in oil palm agroecosystem? Ornithol Sci., 18(2): 127-134.

Azhar, B; LIndenmayer, D B; Wood, J; Fischer, J; Manning, A; Mcelhinny, C and Zakaria, M (2011).
The conservation value of oil palm plantation estates, smallholdings and logged peat swamp forest for birds. Forest Ecol. Manag., 262(12): 2306-2315.

Azhar, B; Puan, C L; Aziz, N; Sainuddin, M; Adila, N; Samsuddin, S; Asmah, S; Syafiq, M; Syafiq, A R; Hafizuddin, A; Hawa, A and Jamian, S (2015). Effects of in situ habitat quality and landscape characteristics in the oil palm agricultural matrix on tropical understory birds, fruit bats and butterflies. Biodiver. Conserv., 24(12): 31253144 .

Buskirk, W H and McDonald, J L (1995). Comparison of point count sampling regimes for monitoring forest birds. Monitoring Bird Populations by Point Counts. Gen. Tech. Rep. PSW-GTR-149. Albany, CA: Pacific Southwest Research Station, Forest Service, US Department of Agriculture.

Chang, P K; Puan, C L; Yee, S A and Abu, J (2017). Vocal individuality of Large-tailed Nighjar (Caprimulgus macrurus) in Peninsular Malaysia. Bioacoustics, 27(2). https: / / doi.org/10.1080/ 09524622.2017.1292408

Delport, W; Kemp, A C and Ferguson, J W H (2002). Vocal identification of individual African Wood Owls Strix woodfordii: A technique to monitor long-term adult turnover and residency. Ibis, 144(1): 30-39.

Gerhardt, R P (1991). Response of Mottled owls to broadcast of conspecific call. J. Field Ornithol., 62: 239244.

Ghazali, A; Asmah, S; Syafiq, M; Yahya, M S; Aziz, N; Tan, L P; Norhisham, A R; Puan, C L; Turner, E C and Azhar, B (2016). Effects of monoculture and polyculture farming in oil palm smallholdings on terrestrial arthropod diversity. J. Asia Pac. Entomol., 19(2): 415-421.

Hafidzi, M N and Naim, M (2003). The use of the Barn Owl, Tyto alba to suppress rat damage in rice fields in Malaysia. ACIAR Monogr. Ser., 96: 274-276.

Hausleitner, D and Bio, R P (2006). Inventory Methods for Owl Surveys. Standards for Components of British Columbia's Biodiversity No. 42. Ecosystem Branch of the Ministry of Environment for the Resources Information Standards.

IUCN (2018). The IUCN Red List of Threatened Species. Version 2018-2. http: / / www.iucnredlist.org, accessed on 14 November 2018.

Kemp, A; Kemp, M and Thong-Aree, S (2009). Surveys of nocturnal birds at Bala rainforest, southern Thailand. Forktail, 25: 117-124. 
König, C; Weick, F and Becking, J H (1999). Owls: A Guide to the Owls of the World. Vol. 12. Christopher Helm Publishers Incorporated. 462 pp.

MET (2014). Malaysian Meteorological Department - Selangor weather forecast. http:/ / www.met.gov. my/web metmalaysia/forecasts/general/districts., accessed on 12 Jun 2018.

Naim, M; Hafidzi, M N; Azhar, K and Jalila, A (2010). Growth performance of nestling barn owls, Ty to alba javanica in rat baiting area in Malaysia. ARPN J. Agric. \& Biol., Sci., 5: 1-13.

Najmi-Hanis, Z; Puan, C L; Zakaria, M and Azhar, B (2016). Home range and activity patterns of Sunda scops-owl in Peninsular Malaysia. Raffles B. Zool., 64: 28-32.

Newton, I; Kavanagh, R; Olsen, J and Taylors, I (2002). Ecology and conservation of owls. Proc of the Owls 2000 Conferences. Canberra, Australia. CSIRO Publishing, Canberra. 400 pp.

Ojwang, D O and Oguge, N O (2003). Testing a biological control program for rodent management in a maize cropping system. Rats, Mice and People: Rodent Biology and Management (Singleton, G R; Hinds, L A; Krebs, C J and Spratt, D M eds.). Australia Centre for International Agricultural Research, Canberra. p. 251-253.

Pilla, P; Puan, C L; Lim, V C; Azhar, B and Zakaria, M (2018). Sunda scops-owl density estimation via distance sampling and call playback. Sains Malays., 47(3): 441-446.

Puan, C L; Goldizen, A W; Zakaria, M; Hafidzi, M N and Baxter, G S (2011). Absence of differential predation on rats by Malaysian barn owls in oil palm plantations. J. Raptor Res., 45(1): 71-78.

Puan, C L; Baxter, G S; Goldizen, A W; Zakaria, M and Hafidzi, M N (2012). Barn owl predatory behavior and response to prey abundance: Towards an ecologically-based agricultural practice. Ornis Mongolia, 1: 63-66.

Puan, C L (2013). Integrating Ecology into Rodents Pest Management in Oil Palm Agroecosystem. University Putra Malaysia Press, Serdang, Selangor, Malaysia. 100 pp.

Puan, C L; Yong, D L; Azhar, B; Phua, M H and Lim, K C (2015). Ecological correlations of nocturnal bird assemblages in Malaysian Borneo. Forktail, 31: 82-86.

Ralph, C J and Sauer, J R (1995). Monitoring Bird Populations by Point Counts. Department of
Agriculture, Forest Service, Pacific Southwest Research Station, Albany, New York. 191 pp.

Robson, C (2011). A Field Guide to the Birds of SouthEast Asia. New Holland. London. 544 pp.

Salim, H; Noor, H M; Tajudin, R; Hamid, N H; Omar, D; Kasim, A and Abidin, C M R Z (2016). Effects of rodenticide on growth of nestling barn owl, Tyto alba javanica in oil palm plantations. J. Oil Palm Res. Vol. 28(1): 16-25.

Syafiq, M; Atiqah, A R N; Ghazali, A; Asmah, S; Yahya, M S; Aziz, N; Puan, C L and Azhar, B (2016). Responses of tropical fruit bats to monoculture and polyculture farming in oil palm smallholdings. Acta Oecol., 74: 11-18.

Takats, D L; Francis, C M; Holroyd, G L; Duncan, J R; Mazur, K M; Cannings, R J; Harris, W and Holt, D (2001). Guidelines for Nocturnal Owl Monitoring in North America. Edmonton: Beaverhill Bird Conservatory and Bird Studies Canada. 36 pp.

Thomas, L; Buckland, S T; Rexstad, E A; Laake, J L; Strindberg, S; Hedley, S L; Bishop, J R B; Marques, T A and Burnham, K P (2010). Distance software: Design and analysis of distance sampling surveys for estimating population size. J. Appl. Ecol., 47(1): 5-14.

Wells, D R (1999). The Birds of the Thai-Malay Peninsula: Non-passerines. Vol. 1. Academic Press, London. 648 pp.

Yahya, M S; Puan, C L; Azhar, B; Atikah, S N and Ghazali, A (2016). Nocturnal bird composition in relation to habitat heterogeneity in small scale oil palm agriculture in Malaysia. Agric. Ecosyst. $\mathcal{E}$ Environ., 233: 140-146.

Yahya, M S; Syafiq, M; Ashton-Butt A; Ghazali, A; Asmah, S and Azhar, B (2017). Switching from monoculture to polyculture farming benefits birds in oil palm production landscapes: Evidence from mist-netting data. Ecol. Evol., 7(16): 6314-6325. DOI:10.1002/ ece3.3205.

Yee, S A; Puan, C L; Chang, P K and Azhar, B (2016). Vocal individuality of Sunda scops-owl (Otus lempiji) in Peninsular Malaysia. J. Raptor Res., 50(4): 379-390.

Yee, S A; Puan, C L and Chang, P K (2018). Territorial and duet calls of three Malaysian owl species. Sains Malays., 47(7): 1439-1445. 